Original Article

\title{
PROTECTIVE EFFECT OF MORINGA OLEIFERA SEED EXTRACT ON CISPLATIN INDUCED NEPHROTOXICITY IN RATS
}

\author{
FATEN I. ELSAYED ${ }^{1 *}$, FATMA ELGENDEY², RANIA M. WAHEED ${ }^{3}$, MONA A. EL-SHEMY ${ }^{4}$
}

1Department of Pharmacology, Faculty of Veterinary Medicine, Benha University, Egypt, ${ }^{2}$ Department of Animal Wealth Development (Genetic and Genetic Engineering), Faculty of Veterinary Medicine, Benha University, Egypt, ${ }^{3}$ Department of Forensic Medicine and Toxicology, Faculty of Veterinary Medicine, Benha University, Egypt, ${ }^{4 *}$ Department of Clinical Pathology, Faculty of Veterinary Medicine, Benha University, Moshtohor, Toukh 13736, Qalyubia, Egypt

Email: Fatenibrahim73@yahoo.com

Received: 27 Feb 2021, Revised and Accepted: 02 Apr 2021

\begin{abstract}
Objective: The main objective of this study is to investigate the antioxidant and nephroprotective efficacy of moringa oleifera seed extract (MOSE) against cisplatin which induced acute renal injury.

Methods: Forty male Wister rats were equally segregated into 4 groups ( 10 rats per group): group I ( $0.5 \mathrm{ml}$ of sterile saline orally), group II (200 mg MOSE $/ \mathrm{kg} \mathrm{b}$. wt orally for 10 consecutive days), group III $\left(7.5 \mathrm{mg}\right.$ cisplatin $/ \mathrm{kg} \mathrm{b}$. wt $/$ intraperitonially as a single dose on the $5^{\text {th }}$ day of the experiment) and group IV (200 mg moringa oleifera seed extract (MOSE)/kg orally for $10 \mathrm{~d}$ followed by $7.5 \mathrm{mg}$ cisplatin/kg body weight/intraperitonially once as a single dose on the $5^{\text {th }}$ day of the experiment. Serum biochemical analysis of renal biomarkers (urea, uric acid, and creatinine), oxidative stress markers (malondialdehyde [MDA]), a crucial antioxidant enzyme (catalase) and the expression of renal activity interleukin (IL)-6, (IL)-10 and Tumer necrotic factor (TNF- $\alpha$ ) mRNA were determined. Histopathological examination of renal tissue was done.

Results: Cisplatin induced renal damage, increased renal biomarkers (urea, creatinine and uric acid) $(375.87 \pm 1.65,5.238 \pm 0.25,4.47 \pm 0.25)$. Tissue concentrations of malondialdehyde, IL- 6 and TNF- $\alpha .(387.56 \pm 0.97,2.188 \pm 0.20,3.06 \pm 0.27)$ compared to control group $(140.58 \pm 1.25,0.938 \pm 0.017$, $1.24 \pm 0.17),(163.99 \pm 1.34,1.008 \pm 0.05,0.982 \pm 0.026)$ Moreover, cisplatin induced significantly down-regulation of anti-inflammatory (IL-10) and catalase $(0.780 \pm 0.47,1.62 \pm 0.06)$ compared to control one $(1.010 \pm 0.02,3.12 \pm 0.11)$. The histopathological examination showed renal tissue damage and degeneration of tubules in the cortical portion in cisplatin group. However, interestingly concurrent adminsteration of the MOSE with cisplatin can alleviated the renal damage, oxidative stress and renal toxicity caused by cisplatin.
\end{abstract}

Conclusion: These results suggest that the antioxidant and the anti-inflammatory effects of MOSE alleviate the cisplatin-induced nephrotoxicity.

Keywords: Cisplatin, Moringa Oleifera, Oxidative stress, Nephrotoxicity, Cytokines

(C) 2021 The Authors. Published by Innovare Academic Sciences Pvt Ltd. This is an open access article under the CC BY license (https://creativecommons.org/licenses/by/4.0/)

DOI: https://dx.doi.org/10.22159/ijpps.2021v13i5.41125. Journal homepage: https://innovareacademics.in/journals/index.php/ijpps.

\section{INTRODUCTION}

Cisplatin is an important anticancer drug. It kills cancer cells via various mode of actions varying from oxidative stress, reactive oxygen species production, lipid peroxidation and activation of pro-inflammatory cytokines. Knowing these mechanisms of action may be an effective way in the strategy of prevention of its side effects on normal cells [1]. Despite considering it as a useful and effective drug in the treatment of many solid tumors, it has many hazard effects including hepatotoxicity, sever kidney injury, ototoxicity and cardiac toxicity [2]. The cisplatin-induced kidney injury remains a serious complication that still lacks effective ways of prevention.

Nutraceuticals from medicinal plants are considered the most desired adjunctive therapy with chemotherapeutic drugs in the treatment of most cancers. MOSE, is one of these effective plants. Moringa oleifera belognes to family Moringaceae is an effective remedy for malnutrition. Moringa is rich in nutrion owing to the presence of essential phytochemicals present in its leaves, ponds and seeds [3]. Moringa leaf extract is rich in antioxidants, polyphenols, oxidase and catalase. Accordingly, it exhibited a great pharmacological and nutritional benefits including protection against hepatorenal, cardiovascular and neurological disorders. It also has anti-inflammatory, antipyretic, anticancer and antioxidant activities [4,5].

The pharmacological adjunctive usage of moringa oleifera to alleviate the cisplatin induced nephrotoxicity was the main objective of this study.

\section{MATERIALS AND METHODS}

Plant and chemicals

\section{Moringa oleifera}

The seeds of Moringa oleifera were purchased from Haraz Company of agricultural seeds, spices and medicinal plants, Cairo, Governorate, Egypt. The seeds were collected in March 2019.

\section{Preparation of extract of Moringa oleifera seeds}

Moringa oleifera seeds were flowed back in tap water and then with bi-distilled water, dried at room temperature and coarsely minced using a pestle and mortar. Extracts were prepared by macerating a weighed amount of the minced parts $(200 \mathrm{~g})$ in volume (2 Liters) of water/organic solvent (bi-distilled water: absolute ethanol, 70:30, and $\mathrm{v} / \mathrm{v}$ ). Maceration continued for $72 \mathrm{~h}$ in freezing with intermittent shaking. The extract was then strained through muslin mesh, filtered through what man paper (1). The obtained filtrate was then concentrated using a shaking water bath at $70{ }^{\circ} \mathrm{C}$ in a wide-mouthed containers and brown semisolid extract was obtained. It was then weighed $(25 \mathrm{~g})$. It re-dissolving in measured amount of iso saline $(0.85 \%, \mathrm{w} / \mathrm{v})$. The extract was stored in airtight container in freezing below $10^{\circ} \mathrm{C}$. a stock solution was diluted which were used for the antioxidant activity testing. For in vivo studies [6]. It was used as a dose of (200 mg/kg b. wt MOSE orally for 10 consecutive days) [7].

Chemicals, reagents and kits

Cisplatin was used under the trade name of (Cytoplatin 10 aquas) imported by star INT company and manufacture by CIPLA LTD. Each 
$20 \mathrm{ml}$ vial contain $10 \mathrm{mg}$ cisplatin. It was used at dose of $7.5 \mathrm{mg} / \mathrm{kg}$ b. wt at the $5^{\text {th }}$ day of the experiment [8].

\section{Kits}

Kits for estimating Urea, creatinine and uric acid were supplied by Centronic GmbH Company Germany by chem7, Kits for estimating of oxidative stree marker Malondialdehyde (MDA), catalase (CAT) in kidney homogenate were purchased from BioDiagnostic Company, Cairo, Egypt by spectro nanodrop. Genes expression was made using High Capacity cDNA Reverse Transcription Kit (Applied Biosystems, CA, USA), and SYBR green master (Applied Biosystems, CA, USA)

\section{Animals}

About forty healthy Wister male rats weighting 200-250 gm were obtained from the animal house of faculty of veterinary medicine, Benha University. They were fed on standard rodent diet and clean water ad libitum. Rats were left for two weeks for acclimatization before the beginning of the experiment.

\section{Experimental design and treatment protocol}

Forty male Wistar rats were divided randomly into 4 groups (10 animals per group). Group I (control group) they were administered $0.5 \mathrm{ml}$ of saline orally for 10 consecutive days. Group II (moringa group) they were administered $200 \mathrm{mg} / \mathrm{kg} \mathrm{b}$. wt Moringa oleifera seed extract (MOSE) orally for 10 consecutive days. Group III (cisplatin group) they were administered cisplatin at dose of 7.5 $\mathrm{mg} / \mathrm{kg}$ body weight/intraperitonially as single dose on the $5^{\text {th }}$ day of experiment. Group IV (Cis+Moringa), they were administered Moringa oleifera seed extract MOSE at dose of $200 \mathrm{mg} / \mathrm{kg}$ orally for $10 \mathrm{~d}$ and single dose of cisplatin at dose of $7.5 \mathrm{mg} / \mathrm{kg}$ body weight/intraperitonially on the $5^{\text {th }}$ day of experiment one hour prior to dose of MOSE.

\section{Blood sampling}

At the end of the experiment blood samples were taken from each rat for biochemical analysis from the median canthus of the eye. Blood sample was collected without anticoagulant for separation of clear serum for biochemical analysis. These serum samples were used for biochemical analysis of (creatinine, urea and Uric acid).

\section{Tissue samples}

At the end of the experiment all rats were scarified, and tissue samples were taken from kidney for both biochemical study of oxidative stress markers (MDA, CAT, IL-10, IL-6 and TNF- $\alpha$ ) and for histopathological examination.

\section{Assay methods}

\section{Serum biochemical analysis}

Serum creatinine was measured spectrophotometrically according to [9] using specific kits from Diamond Company. Serum urea concentration was determined according to [10] by kits from Diamond Company.

\section{Evaluation of renal oxidative stress markers}

Both kidneys were taken immediately after scarification, washed in physiological saline. One kidney was preserved at-80c until preparation of tissue homogenate which used for assessment of (MDA and CAT) levels calorimetrically. According to $[11,12]$ respectively.

\section{Gene's expression by real time PCR}

Total RNA was isolated from kidney tissue using the Total RNA Isolation System (Promega Co., Madison, WI, USA) according to the manufacturer's protocol. Briefly, RNA was extracted and resuspended in $50 \mu \mathrm{L}$ RNase free water, then stored-80 ${ }^{\circ} \mathrm{C}$. The total RNA concentration was determined spectrophotometrically (SPECTRO star Nano, BMG Labtech Co., Ortenberg, Germany) and then $1 \mu \mathrm{g}$ of RNA was used for cDNA synthesis using the High Capacity cDNA Reverse Transcription Kit (Applied Biosystems, CA, USA). The condition was achieved in line with the kit of cDNA reverse transcription as follow; step I (10 min/25 $\left.{ }^{\circ} \mathrm{C}\right)$, step II (120 $\left.\min / 37^{\circ} \mathrm{C}\right)$, step III $\left(5 \mathrm{~min} / 85^{\circ} \mathrm{C}\right)$ and step IV $\left(\infty \sim\right.$ at $\left.4{ }^{\circ} \mathrm{C}\right)$, then, 1 $\mu \mathrm{g}$ of the obtained cDNA with the SYBR green master mix were used in a total of $20 \mu \mathrm{l}$ reaction volume $7 \mu \mathrm{l}$ of nuclease-free water, $10 \mu \mathrm{l}$ of master mix, $1 \mu \mathrm{l}$ of forward primer, $1 \mu \mathrm{l}$ of reverse primer, and 1 $\mu \mathrm{l}$ of DNA template) for HSP70 and $\beta$-actin gene amplification using the following primers:

IL 6 Forward GACTTCCAGCCAGTTGCCTTCTTG, IL 6 Reverse TGGTCTGTTGTGGGTGGTATCCTC, IL 10 Forward TGCCAAGC CTTGTCAGAAATGATCAAG, IL 10 Reverse TGCCAAGCCTTGTCAG AAATGATCAAG, TNF- $\alpha$ Forward AAATGGGCTCCCTCTCATCAGTTC, TNF- $\alpha$ Reverse TCCGCTTGGTGGTTTGCTACGAC, GAPDH 5'-AACTCCCA TTCCTCCACCTT- 3 ' forward, 5'-GAGGGCCTCTCTCTTGCTCT-3' reverse.

The genes were amplified then the expression levels were analyzed using a real-time PCR (7500 Fast Real-Time PCR System, Applied Biosystems, CA). The cycling condition was justified first the initial activation $\left(3 \mathrm{~min} / 95^{\circ} \mathrm{C}\right)$, denaturation $\left(3 \mathrm{~s} / 95{ }^{\circ} \mathrm{C}\right)$, annealing/ extension $\left(30 \mathrm{~s} / 60^{\circ} \mathrm{C}\right)$, and the number of cycles were 40 according to [13]. All gene expression level was normalized against the GAPDH gene.

\section{Histopathology examination}

Autopsy from the kidney of rats in different groups were taken and fixed in $10 \%$ formol saline for twenty-four hours. Washing by tap water then serial dilutions of alcohol (methyl, ethyl and absolute ethyl) were used for dehydration. Specimens were cleared in xylene and embedded in paraffin at 56 degree in hot air oven for twentyfour hours. Paraffin bees wax tissue blocks were prepared for sectioning at 4 microns thickness by sledge microtome. The tissue sections were taken on glass slides, deparaffinized, stained by hematoxylin and eosin stain for examination through the light electric microscope [14].

\section{Statistical analysis}

The results were done as mean \pm SE of the experimental groups using (one-way ANOVA) followed by Duncan's multiple range test. All analysis was performed by Statistical Package for Social science Software (SPSS (16) software (SPSS Inc., Chicago, USA).

\section{RESULTS}

There was no mortality observed in any group of the experiment during the period of the experiment. Regarding to the biochemical renal parameters (urea, creatinine and uric acid) there was significant increase $(\mathrm{p}<0.001)$ in the urea $(375.87 \pm 1.65)$, creatinine $(5.23 \pm 0.25)$ and uric acid $(4.47 \pm 0.25)$ levels in the cisplatin group when compared to control group, moringa group and Cis + Moringa group table 1 .

Analysis of the lipid peroxidation parameter MDA, there was significant elevation in MDA level $(\mathrm{p}<0.001)$ in the cisplatin group (387.5 \pm 1.49 ) when compared to control group (163.99 \pm 1.3$)$, moringa group (213.34 \pm 1.3 ) and Cis + Moringa group (180.68 \pm 0.97$)$ table 2 .

The catalase level showed significant decrease $(\mathrm{p}<0.001)$ in cisplatin group $(1.62 \pm 0.06)$ when compared to control group $(3.12 \pm 0.11)$, moringa group (3.56 \pm 0.17$)$ and Cis + Moringa group (2.15 \pm 0.08$)$.

The IL-6 gene expression level was significantly higher $(\mathrm{p}<0.001)$ in the cisplatin group $(2.19 \pm 0.20)$ than in the control, Cis+Moringa and Moringa groups $(1.01 \pm 0.05,1.40 \pm 0.02$, and $1.34 \pm 0.05$ respectively). The gene expression level of IL-10 was down regulated in the kidney tissue of the Cisplatin group rats $(0.78 \pm 0.473)$ compared with other groups and TNF- $\alpha$ upregulated in cisplatin groups (3.0620 \pm 0.277 ) compared with other groups. All these data illustrated in table 3 .

\section{Histopathological findings}

Regarding to the histopathological examination of the renal tissue, the cisplatin group showed focal infiltration of the inflammatory cells in between the degenerated tubule in the cortical portion fig. $1(\mathrm{C})$ with congestion in the blood vessels and glomeruli as well as degeneration and desquamation in the tubular lining epithelium fig. $1(\mathrm{D}$ and E). There was no histopathological alteration and the glomeruli and tubules at the cortex appeared with normal histological structure in control group fig. 1(A) and in moringa group 
fig. 1(B). The cortex showed normal histological structure in cisplatin+moringa group fig. $1(\mathrm{~F})$, while the corticomedullary portion showed degeneration and desquamation in the lining epithelium in fig. 1(G).

Table 1: Effect of oral administration of MOSE at $200 \mathrm{mg} / \mathrm{kg}$ body weight for successive $10 \mathrm{~d}$ on renal biomarker (Urea, creatinine, uric acid) on cisplatin $(7.5 \mathrm{mg} / \mathrm{kg} \mathrm{b}$. wt.) intoxicated rats.(n=10)

\begin{tabular}{llll}
\hline Groups/parameters & Urea (mg/d) & Creatinine (mg/dl) & Uric acid (mg/dl) \\
\hline Control & $140.58 \pm 1.25^{\mathrm{c}}$ & $0.938 \pm 0.017^{\mathrm{c}}$ & $1.246 \pm 0.17^{\mathrm{b}}$ \\
Moringa & $139.6 \pm 1.58^{\mathrm{c}}$ & $0.946 \pm 0.022^{\mathrm{c}}$ & $1.540 \pm 0.22^{\mathrm{b}}$ \\
Cisplatin & $375.87 \pm 1.65^{\mathrm{a}}$ & $5.238 \pm 0.25^{\mathrm{a}}$ & $4.47 \pm 0.25^{\mathrm{b}}$ \\
Cis.+Moringa & $192.30 \pm 1.51^{\mathrm{b}}$ & $2.276 \pm 0.22^{\mathrm{b}}$ & $2.377 \pm 0.22^{\mathrm{b}}$ \\
\hline
\end{tabular}

Data are represented as (mean of 10rats $\pm S$. E). Mean values with different superscripted letters in the same column are significantly different

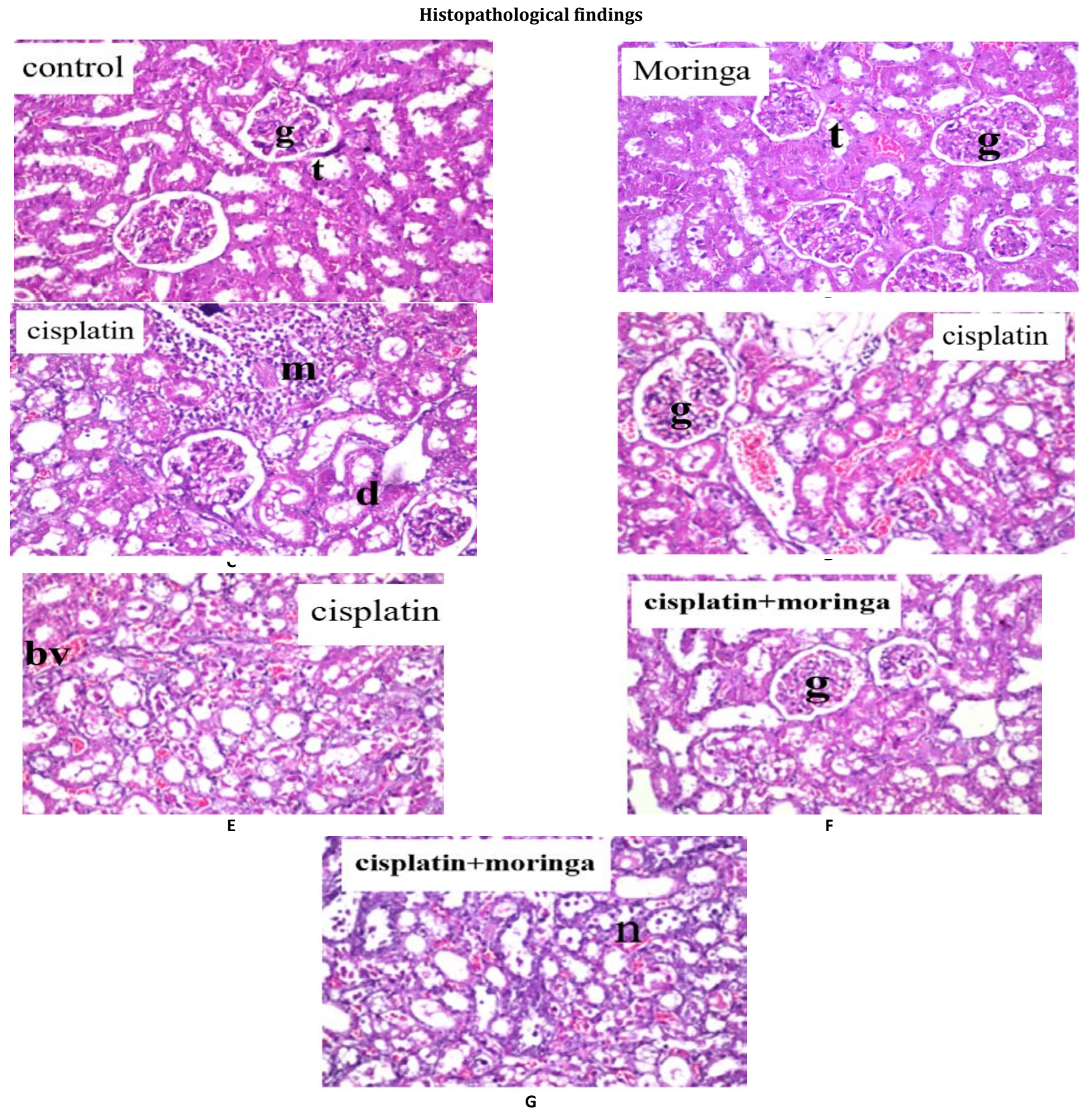

Fig. 1: Histopathological examination of rat kidney sections of different experimental groups stained with (HandE X40). There was no histopathological alteration and the normal histological structure of the glomeruli and tubules at the cortex in control (A) and moringa group (B). The cortical portion showed focal inflammatory cells infiltration in between the degenerated tubule. m: Focal inflammatory

cell infiltration g: glomeruli d: degenerated tubules at cisplatin group (C). Congestion in the blood vessels and glomeruli as well as degeneration and desquamation in the tubular lining epithelium in cisplatin group (Dand E). bv: congested blood vessels, g: glomeruli. Cortex showed normal histological structure in cisplatin+moringa group (F), while the corticomedullary portion showed degeneration and desquamation in the lining epithelium in cisplatin+moringa group (G) 
Table 2: Effect of oral administration of MOSE at $200 \mathrm{mg} / \mathrm{kg}$ body weight for successive $10 \mathrm{~d}$ on renal oxidative stress biomarker (MDA, CAT) on cisplatin $(7.5 \mathrm{mg} / \mathrm{kg}$ b. wt.) intoxicated rats. $(\mathrm{n}=10)$

\begin{tabular}{lll}
\hline Groups/parameters & MDA (nmol/gm) & CAT (U/gm) \\
\hline Control & $163.99 \pm 1.34^{\mathrm{d}}$ & $3.12 \pm 0.11^{\mathrm{b}}$ \\
Moringa & $213.34 \pm 1.33^{\mathrm{b}}$ & $3.56 \pm 0.17^{\mathrm{a}}$ \\
Cisplatin & $387.50 \pm 1.49^{\mathrm{a}}$ & $1.62 \pm 0.06^{\mathrm{d}}$ \\
Cis. + Moringa & $180.68 \pm 0.97^{\mathrm{c}}$ & $2.15 \pm 0.08^{\mathrm{c}}$ \\
\hline
\end{tabular}

Data are represented as (mean of 10rats \pm SE). Mean values with different superscriped letters in the same column are significantly different

Table 3: Effect of oral administration of MOSE at $200 \mathrm{mg} / \mathrm{kg}$ body weight for successive $10 \mathrm{~d}$ on renal IL-6, IL-10 and TNF- $\alpha$ on cisplatin (7.5 mg/kg b. wt.) intoxicated rats.(n=10)

\begin{tabular}{llll}
\hline Groups/parameters & IL-6 & IL-10 & TNF- $\alpha$ \\
\hline Control & $1.0080 \pm 0.05^{\mathrm{c}}$ & $1.010 \pm 0.02^{\mathrm{b}}$ & $0.9820 \pm 0.026^{\mathrm{b}}$ \\
Moringa & $1.3420 \pm 0.05^{\mathrm{b}}$ & $1.1520 \pm 0.04^{\mathrm{b}}$ & $1.0180 \pm 0.27^{\mathrm{b}}$ \\
Cisplatin & $2.1886 \pm 0.20^{\mathrm{a}}$ & $0.780 \pm 0.47^{\mathrm{c}}$ & $3.0620 \pm 0.277^{\mathrm{a}}$ \\
Cis.+Moringa & $1.4020 \pm 0.02^{\mathrm{b}}$ & $1.832 \pm 0.13^{\mathrm{a}}$ & $1.5880 \pm 0.19^{\mathrm{b}}$ \\
\hline
\end{tabular}

Data are represented as (mean of 10rats \pm S. E). Mean values with different superscripted letters in the same column are significantly different

\section{DISCUSSION}

Cisplatin is an important anti-neoplastic agent. It is a useful drug in the treating of many types of solid tumors. Nephrotoxicity is the main adverse side effect of cisplatin. This experiment was done to determine the antioxidant and nephroprotective efficacy of MOSE against cisplatin induced acute renal damage. Moringa oleifera seed extract MOSE has antioxidant properties.

Our results showed a state of oxidative stress-mediated renal injury after treatment of rats with a single i. p. dose of cisplatin as it is indicated by significant elevation in serum urea, uric acid, creatinine and renal tissue levels of MDA with significant reduction in renal tissue level of catalase. This state of renal injury was confirmed with histopathological examination of kidney tissue that reviled focal inflammatory cells infiltration in between the degenerated tubules in the cortical portion with degeneration and desquamation in the lining epithelium fig. 1 (c). This state of renal injury may be because of the oxidative stress and inflammatory effects of cisplatin. This injury may be because of the liberated free radicals cause membrane lipid peroxidation and denaturation of both DNA and proteins. This damage leads to enzymatic inactivation and mitochondrial dysfunction that enhance ROS production via the disruption of the respiratory chain [15]. Catalase enzyme is a thiol-containing enzyme. It is an important enzyme for the neutralization of ROS [16, 17].

The increased serum levels of renal biomarkers urea, creatinine, and uric acid after cisplatin administration in a single i. p. dose coincided with [18] who recorded that cisplatin enhances glomerular filtration membrane damage through oxidative stress, inflammation, and apoptosis. This damage resulting in low glomerular filtration rate and loss of normal membrane permeability.

In our study MOSE administration reduced the oxidative stress state through significant reduction in serum creatinine, urea and renal MDA level with significant elevation in the renal catalase level. Our results matched with [19] who said that MOSE protected the renal tissue by restoring the kidney integrity and regenerative capacity and also by decreasing the elevated urea and creatinine in response to exposure to cisplatin. The possible protective effect of Moringa oleifera seed extract (MOSE) on these markers may be a result of the antioxidant action of oleic and linoleic acid, which are both constituents of the moringa plant. In this regard [20]. Reported that any natural compound with antioxidant effects may help in preserving a healthy state when continuously taken naturally or therapeutically. As agreed with [21] who reported that moringa extract effectively inhibit CCL4induced tissue damage due to presence of various antioxidant bioactive compound.

Moringa oleifera seed extract (MOSE) is a highly enriched compound with flavonoids and phenolic constituents, which have a cytoprotective and antioxidant effects on the renal tissue, [22-24]. Antioxidant compounds of plant are able to perform their safety roles in living organisms by stopping free radicals production or by counterbalancing them $[25,26]$.

The antioxidant activity of Moringa oleifera seed extract (MOSE) is thought to be the key factor as a reno protective agent.

In the present study the cisplatin increased the expression levels of IL-6 and TNF- $\alpha$ that is in agreement with [27] were found Many cytokines (e. g. TNF- $\alpha$, IL,-1 and IL-6) are upregulated in the renal tissues inflammatory conditions caused by cisplatin. While the levels of IL6 and TNF $\alpha$ restored to normal levels in the Moringa with cisplatin group because of Moringa has antibiotic, antitrypanosomal, hypotensive, antispasmodic, antiulcer, anti-inflammatory, hypocholesterolemic and hypoglycemic activities [28]. Cisplatin induced TNF- $\alpha$ is highly dependent upon the Reactive oxygen species (ROS) production, NF- $\kappa \mathrm{B}$ and p38 MAPK activation. However, the activation of TNF- $\alpha$ and IL are involved in many signal transduction mechanisms, involving the NF- $\kappa$ B and AP-1 pathways. Exactly, the stress-activated group of MAPKs (JNK and p38) is strongly activated by TNF- $\alpha$ and IL [29].

Antioxidant property of Moringa which could be possibly the primary mechanism of protection against cisplatin toxicity due to Moringa contains antioxidant compounds that was confirmed in this study, such as vitamin A, which quench ROS, combined with metal ions and regenerate membrane-bound antioxidants. These findings are matched with previous reports of [30].

Several studies have expressed that cytokines such as IL-10 counterbalance or inhibit the increase in other pro-inflammatory cytokine levels in order to protect tissue against injury in various pathophysiological conditions. [31]. IL-10 exerts anti-inflammatory and anticytotoxic effect in kidney injury accompanied with lupus nephritis, immune complex glomerulonephritis and ischemic or cisplatin-induced nephrotoxicity [32]. The findings of the other study stated the animals receiving cisplatin the levels of IL-10 decreased [33]. While IL-10 gene expression regained to normal level with administration of Moringa with cisplatin to normal level due to moringa decrease inflammation and oxidative stress caused by cisplatin corresponding to the findings have revealed that Moringa prevent oxidative stress-mediated toxicity in the brain tissue, testis, liver, and kidney of rats [34-36]. Moringa leaves extracts have a powerful antioxidant action against free radicals, prevent oxidative damage to major biomolecules and provide substantial protection against oxidative damage [37-38].

\section{CONCLUSION}

The results of this study show a possible explanation for the protective effects of Moringa oleifera seed extract (MOSE) against cisplatin induced nephrotoxicity. Concurrent administration leads to significant decreased renal biomarkers (urea, creatinine and uric acid) $(192.30 \pm 1.51,2.276 \pm 0.22,2.377 \pm 0.22)$, tissue concentrations of 
malondialdehyde, IL- 6 and TNF- $\alpha$. $(180.68 \pm 0.97,1.40 \pm 0.02$, $1.58 \pm 0.19)$ compared to cisplatin group $(375.87 \pm 1.65,5.238 \pm 0.25$, $4.47 \pm 0.25)$, (387.50 $\pm 1.49,2.188 \pm 0.20,3.06 \pm 0.27$ ) Moreover, induced significantly up-regulation of anti-inflammatory (IL-10) and catalase $(1.832 \pm 0.13,2.15 \pm 0.08)$ compared to cisplatin group $(0.780 \pm 0.47$, $1.62 \pm 0.06$ ). All this enhanced with a great protective effect of MOSE on renal tissue represented in no histopathological alteration. It may be due to its antioxidant scavenging properties and down regulation of the proinflammatory cytokine like (IL-6). These ensures the possible applied values of MOSE in preventing nephrotoxicity.

\section{FUNDING}

Nil

\section{CONFLICT OF INTERESTS}

No potential conflict of interest was reported by the authors.

\section{AUTHORS CONTRIBUTIONS}

All Authors have contributed equally.

\section{REFERENCES}

1. Dasari S, Tchounwou PB. Cisplatin in cancer therapy: molecular mechanisms of action. Eur J Pharmacol 2014;740:364-78.

2. Dugbartey GJ, Peppone LJ, Graaf IAM. An integrative view of cisplatin-induced renal and cardiac toxicities: molecular mechanisms, current treatment challenges and potential protective measures. Toxicology 2016;37:158-66.

3. Sameeh AM, Reham IM, Amina RA, Abdel Razik HF. The protective effect of moringa tea against cypermethrin-induced hepatorenal dysfunction, oxidative stress, and histopathological alterations in female rats. Asian J Pharm Clin Res 2018;11:111-7.

4. Kou X, Li B, Olayanju J, Drake J, Chen N. Nutraceutical or pharmacological potential of Moringa oleifera Lam. Nutrients 2018;10:343.

5. Khalil SR, Abdel Motal SM, Abd-Elsalam M, El-Hameed NEA, Awad A. Restoring strategy of ethanolic extract of Moringa oleifera leaves against Tilmicosin-induced cardiac injury in rats: targeting cell apoptosis-mediated pathways. Gene 2020;730:144272.

6. Harborne JB. Phytochemical methods a guide to modern techniques of plant analysis; 1973.

7. Purena R, Seth R, Bhatt R. Protective role of emblica officinalis hydro-ethanolic leaf extract in cisplatin induced nephrotoxicity in rats. Toxicol Rep 2018;5:270-7.

8. Boorla SK, Panchagiri S, Shastrala KK, Bonagiri R, Vangala M. Evaluation of role of atorvastatin in cisplatin induced nephrotoxicity in wistar rats. Glob J Pharmacol 2014;8:279-83.

9. Murray R Creatinine, Kaplan A. Clin Chem The C. V. Mos by Co. Si louis. Tronto. Princeton; 1984. p. 1261-6.

10. Kaplan A, Urea Kaplan A. Clin Chem The C. V. Mos by Co. Si louis. Tronto. Princeton; 1984. p. 1257-60.

11. Ohkawa H, Ohishi N, Yagi K. Assay for lipid peroxides in animal tissues by thiobarbituric acid reaction. Anal Biochem 1979;95:351-8.

12. Aebi H. Catalase in vitro. In: Oxygen radicals in biological systems. Methods in enzymology. Vol. 105. Edited by L. Parker. Academic Press: Orlando, Fla; 1984. p. 121-6.

13. Zhao FJ, Ma JF, Meharg AA, Grath SP. Arsenic uptake and metabolism in plants. New Phytol 2009;181:777-94.

14. Banchroft JD, Stevens A, Turner DR. Theory and practice of histological techniques $4^{\text {th }}$ ed. Churchill living stone New York: London, San Francisco, Tokyo; 1960. p. 800.

15. Miller RP, Tadagavadi RK, Ramesh G, Reeves WB. Mechanisms of cisplatin nephrotoxicity. Toxins 2010;2:2490-518.

16. Abdel Daim MM, El-Ghoneimy A. Synergistic protective effects of ceftriaxone and ascorbic acid against subacute deltamerthrininduced nephrotoxicity in rats. Ren Fail 2015;37:297-304.

17. Kawai Y, Satoh T, Hibi D, Ohno Y, Kohda Y, Miura K, et al. The effect of antioxidant on development of fibrosis by cisplatin in rats. J Pharmacol Sci 2009;111:433-43.
18. Dwivedi VK, Bhatanagar A, Chaudhary M. Protective role of ceftriaxone plus sulbactam with VRP1034 on oxidative stress, hematological and enzymatic parameters in cadmium toxicity induced rat model. Interdiscip Toxicol 2012;5:192-200.

19. Mousa AA, El-Gansh HAI, Eldaim MAA, Mohamed MAE, Morsi AH, El Sabagh HS. Protective effect of moringa oleifera leaves ethanolic extract against thioacetamide-induced hepatotoxicity in rats via modulation of cellular antioxidant, apoptotic and inflammatory markers. Environ Sci Pollut Res Int 2019;26:32488-504.

20. Crona DJ, Faso A, Nishijima TF, McGraw KA, Galsky MD, Milowsky MI. A systemic review of strategies to prevent cisplatin-induced nephrotoxicity. Oncologist 2017;22:609-19.

21. Rehab AS, Magdy MM, Mahmoud BA, Marwa MS. Assessment effect of aloe vera, azadirachta indica and moringa oleifera aqueous extracts on carbon tetrachloride-induced hepatotoxicity in rats. Int J Pharm Pharm Sci 2016;8:83-9.

22. Mallya R, Chatterjee PK, Vinodini NA, Chatterjee P, Mithra P. Moringa oleifera leaf extract: beneficial effects on cadmium induced toxicities-a review. J Clin Diagn Res 2017;11:CE01-CE04.

23. Ademiluyi AO, Aladeselu OH, Oboh G, Boligon A A. Drying alters the phenolic constituents, antioxidant properties, $\alpha$-amylase and $\alpha$-glucosidase inhibitory properties of Moringa (Moringa oleifera) leaf. Food Sci Nutr 2018;6:2123-33.

24. Oyeleye SI, Adebayo AA, Ogunsuyia OB, Dada FA, Oboh G. Phenolic profile and enzyme inhibitory activities of almond (Terminalia catappa) leaf and stem bark. Int J Food Prop 2017;20:S2810-S282.

25. Gandhi S, Abranov AY. Mechanism of oxidative stress in neurodegeneration. Oxid Med Cell Longev 2012;3:65-8.

26. Oboh G. Effect of blanching on the antioxidant property of some tropical green leafy vegetables. J Med Food 2005;38:513-7.

27. Ramesh G, Reeves WB. TNF- $\alpha$ mediates chemokine and cytokine expression and renal injury in cisplatin nephrotoxicity. J Clin Invest 2002;110:835-42.

28. Coppin JP, Xu Y, Chen H, Pan MH, Ho CT, Juliani R, et al. Determination of flavonoids by LC/MS and anti-inflammatory activity in Moringa oleifera. J Funct Foods 2013;5:1892-9.

29. Arjumand W, Seth A, Sultana S. Rutin attenuates cisplatin induced renal inflammation and apoptosis by reducing $\mathrm{NKkB}$, TNF-a and caspase-3 expression in wistar rats. Food Chem Toxicol 2011;49:2013-21.

30. Hamza AA. Ameliorative effects of Moringa oleifera lam seed extract on liver fibrosis in rats. Food Chem Toxicol 2010;48:345-55.

31. Tadagavadi RK, Reeves WB. Endogenous IL-10 attenuates cisplatin nephrotoxicity: role of dendritic cells. J Immunol 2010;185:4904-11.

32. Deng J, Kohda Y, Chiao H. Interleukin-10 inhibits ischemic and cisplatin-induced acute renal injury. Kidney Int 2001;60:2118-28.

33. Kim MG, Yang HN, Kim HW. IL-10 mediates rosiglitazoneinduced kidney protection in cisplatin nephrotoxicity. J Korean Med Sci 2010;25:557-63.

34. Abarikwu SO, Benjamin S, Ebah SG, Obilor G, Agbam G. Oral administration of Moringa oleifera oil but not coconut oil prevents mercury-induced testicular toxicity in rats. Andrologia 2017;49:e12597.

35. Famurewa AC, Aja PM, Nwankwo OE, Awoke JN, Maduagwuna EK, Aloke C. Moringa oleifera seed oil or virgin coconut oil supplementation abrogates cerebral neurotoxicity induced by antineoplastic agent methotrexate by suppression of oxidative stress and neuro-inflammation in rats. J Food Biochem 2019;43:e12748.

36. Zeng K Moringa oleifera seed extract protects against brain damage in both the acute and delayed stages of ischemic stroke. Exp Gerontol 2019;122:99-108.

37. Sreelatha S, Padma PR. Antioxidant activity and total phenolic content of Moringa oleifera leaves in two stages of maturity. Plant Food Hum Nutr 2009;64:303-11.

38. Abd-El Reheem AE, Rana AA, Eman MR. Physiological studies of the effect of Moringa olifera and vitamin (C) on hepatotoxicity and oxidative stress induced by lead acetate in male albino rats egypt. Acad J Biol Sci 2019;11:93-104. 